\title{
IMPACT OF TRANSPORTATION AND ENVIRONMENTAL CHANGE ON THE LEVELS ACTH AND CORTISOL IN THE BLOOD OF CARP (CYPRINUS CARPIO L.)
}

\section{WPEYW TRANSPORTU I ZMIANY ŚRODOWISKA NA POZIOM ACTH I KORTYZOLU WE KRWI KARPIA (CYPRINUS CARPIO L.)}

Division of Fish Physiology, Agricultural University of Szczecin, Poland

Present studies yielded the following conclusions: The transport caused statistically significant rise of ACTH and cortisol concentrations in the blood of carp reared in the thermaleffluent channel. Usage of glass tanks for accommodating the fish caused prolongation of the stress reaction and maintenance of high ACTH and cortisol levels beyond the 7-day period monitored in the present experiment.

\section{INTRODUCTION}

Fish culture in post-cooling waters of power plants, offering minimal dependence on seasonal thermal changes, not only enables to rear fishes in a continuous production cycle, but also gives yields substantially higher than traditional systems. It seems, however, that such forcibly high productivity, and also optimization and stabilization of the culture conditions, without necessary stimuli from the natural environment, may turn out to be a reason for the increase in sensitivity of cultured fishes for environmental aggression factors. In the case of fishes, particularly stress-inflicting role play: oxygen deficiency (Soivio and Nikinmaa 1981), rapid temperature changes (Thomas 1990), water composition changes (Mackett et al. 1992), and in the contemporary aquaculture also transportation (Robertson et al. 1988) and pollution of the natural environment (Prost et al. 1995). 
One of the systems responsible for adaptation potential of an organism is the hypothalamus-pituitary-interrenal system (Thomas 1988). In the course of its stimulation, increased or decreased secretion of many hormones takes place (Pickering et al. 1987; Pickering and Potinger, 1989; Donaldson 1990; Thomas 1990). It triggers a number of changes in hematological and biochemical parameters of blood (Soivio and Nikinmaa 1981; Thomas 1984; Prost et al. 1995) causing metabolic (Thomas 1984), immune (Prost et al. 1995), and reproduction disorders (Pickering et al. 1987; Donaldson 1990).

The aim of this study was to determine the transportation impact on ACTH and cortisol concentrations in the blood of carp and to assess the recovery time e.g. the time that has to elapse from the transfer of fish to the moment of regaining the basic concentration of the studied hormones.

\section{MATERIAL AND METHODS}

The experiment was carried out in October, and it was performed on clinically healthy carp individuals at the age of +1 , with the body masses of $610 \pm 70 \mathrm{~g}$. The fish originated from a cage site at the thermal-effluent channel of the Dolna Odra power plant. The water temperature at the day of experiment was $22^{\circ} \mathrm{C}$. The fish were transported for 1 hour in 60-liter barrels, 10 fish in each barrel. Upon the arrival, the fish were transferred to 400 -liter glass tanks, 10 fish in each. The water had been constantly aerated starting 4 days prior the experiment, and the temperature had been maintained at $22^{\circ} \mathrm{C}$. Blood for the studies was sampled from the caudal vein within 7:30 - 8:00 AM before the transfer and on the 1st, 4th, and 7th day since its completion. Each sampling was based on 15 fish. The blood serum was studied for ACTH and cortisol concentrations employing the radioimmunological method, with use of ${ }^{125} \mathrm{~J} \quad$ ACTH (1-39) and ${ }^{125} \mathrm{~J}$ Cortisol from a reagent set of Orion Diagnostica Finland.

The results were statistically processed using Statgraphics ${ }^{\circledR}$ computer software.

\section{RESULTS AND DISCUSSION}

The results are presented in the Tables 1 and 2.

Table 1

Water temperatures $\left({ }^{\circ} \mathrm{C}\right)$ in the thermal-effluent channel of the Dolna Odra power plant in the period from March to October 1995

\begin{tabular}{|l|c|c|c|c|c|c|c|c|}
\hline \multicolumn{1}{|c|}{ Month } & March & April & May & June & July & August & September & October \\
\hline $\begin{array}{l}\text { Minimal } \\
\text { temperature }\end{array}$ & 12.1 & 17.1 & 19.2 & 21.1 & 25.0 & 25.0 & 21.0 & 20.0 \\
\hline $\begin{array}{l}\text { Maximal } \\
\text { temperature }\end{array}$ & 16.3 & 22.2 & 24.6 & 29.5 & 32.1 & 30.8 & 25.4 & 24.2 \\
\hline Average & 13.7 & 19.7 & 22.5 & 25.2 & 29.2 & 25.1 & 23.0 & 22.0 \\
\hline
\end{tabular}


Table 2

Levels of ACTH and cortisol in the blood of carp before and after the transportation and the associated change of environment, $\bar{x} \pm \mathrm{SD}$

\begin{tabular}{|l|c|c|c|c|c|}
\hline \multirow{2}{*}{ Component } & Before & After & \multicolumn{3}{|c|}{ Days $(24 \mathrm{~h})$ in the altered environment } \\
\cline { 4 - 6 } & & & 1 & 4 & 7 \\
\cline { 2 - 6 } & $\mathrm{n}=15$ & $\mathrm{n}=15$ & $\mathrm{n}=15$ & $\mathrm{n}=15$ & $\mathrm{n}=15$ \\
\hline ACTH $(\mathrm{pg} / \mathrm{ml})$ & $50.4 \pm 20.9$ & $511.5 \pm 212.0^{* *}$ & $317.8 \pm 103.8^{* *}$ & $175.7 \pm 65.7^{* *}$ & $76.9 \pm 35.8^{*}$ \\
\hline Cortisol $(\mu \mathrm{mol} / \mathrm{l})$ & $60.7 \pm 10.5$ & $873.3 \pm 240.9^{* *}$ & $720.4 \pm 320.6^{* *}$ & $630.0 \pm 256.2^{* *}$ & $209.3 \pm 90.7^{* *}$ \\
\hline
\end{tabular}

* - significant difference $\mathrm{P} \leq 0.05$.

$* *$ - significant difference $\mathrm{P} \leq 0.01$.

The transportation caused statistically significant $(\mathrm{P} \leq 0.01)$ increase in the levels of $\mathrm{ACTH}$ and cortisol in the blood of the studied fish. The associated change of environment, despite of similar water parameters before and after the transportation, prolonged the period of recovery of the studied hormones levels beyond the 7-day period monitored in the present experiment. On the 1st, 4th, and 7th day after the transportation, the concentrations of ACTH and cortisol were still statistically different $(\mathrm{P} \leq 0.01 ; 0.05)$ from the initial basic levels of these hormones observed in the carp blood before the transportation.

Very high increase in ACTH and cortisol concentrations, observed in the blood serum of the carp after the transfer, suggests that transportation, even relatively short and in convenient conditions, is a particularly strong stress-inflicting factor. Using the glass tanks for accommodating the carp, aimed at following the pace of normalization of the concentrations of the studied hormones, had shown that the recovery was relatively slow and its time went beyond the seven days of monitoring. It seems, however, that the above dynamics of the concentrations of ACTH and cortisol is influenced by the change of environment. It has been proved also by the results of the other authors studying impact of environmental aggression factors, without changes of that environment. These authors stated increase in cortisol concentrations as early as 1 hour since introduction of a stress agent and the recovery to the initial levels after 6 hours from the beginning of experiment (Thomas 1990; Mackett et al. 1992).

In the light of hitherto existing reports, the pathomechanism of the stress reactions of fishes has not been clear yet. However, the involvement of the ophthalmic ventricles, being the structures associated with information transfer from the perimeter to the hypothalamus is now beyond a doubt. Important role is attributed to the external receptors which control the receptive abilities and effective information transmission to the hypothalamus-pituitaryinterrenal pathway (Węgrzynowicz and Gorczyńska 1982; Thomas 1990).

The present experiment is interesting for its discovery of irregular pace of decrease in $\mathrm{ACTH}$ and cortisol concentrations. It was revealed, while comparing the pace of decrease 
of both hormones, that the high cortisol concentration was maintained in fish blood longer than high concentration of ACTH and these two hormones levels were not interrelated in their dynamics. The above phenomenon confirms the previously mentioned statement that placing fish in aquaria was a stress-causing factor of chronic dimensions. Through enlargement of the nuclei of secretory cells, the activity of the interrenal gland becomes substantially stimulated, resulting in release of cortisol without simultaneous activation of the pituitary gland (Van Overbeeke and Mc Bride 1971; Pickering and Pottinger 1989; Weisbart et al. 1989).

The presently obtained results allow for a statement that the transportation and the change in environment, with simultaneous maintaining water parameters, turned out to be especially stress-causing factors for the carp reared in the thermal-effluent channel. It is evident in view of the observed dynamics of changes of ACTH and cortisol-hormones responsible, among other functions, for the adaptive potential of an organism and for longlasting recovery from the changes inflicted upon it.

The presented results were acquired in the course of an experiment ensuring quiet and careful loading and unloading of the fish. It seems, however, that in the course of an uncontrolled handling, occurring in real-life market transportation, such impact may be substantially more severe.

\section{CONCLUSIONS}

1. The transport caused statistically significant rise of $\mathrm{ACTH}$ and cortisol concentrations in the blood of carp reared in the thermal-effluent channel.

2. Usage of glass tanks for accommodating the fish caused prolongation of the stress reaction and maintenance of high ACTH and cortisol levels beyond the 7-day period monitored in the present experiment.

\section{REFERENCES}

Donaldson E.M., 1990: Reproductive indices as measures of the effects of environmental stressors in fish. Am. Fish Soc. Symp., 8: 109-122.

Mackett D.B., W.H. Tam, J.N. Fryer, 1992: Histological changes in insulin-immunoreactive pancreatic beta-cells and suppresion of insulin secretion and somatotrope activity $i$ brook trout intake or exposed to acidic environment. Fish Physiol. Biochem., 7: 229-243.

Pickering A.D., T.G. Pottinger, 1989: Stress responsess and disease in salmonid fish: effects of chronic elevation in plasma cortisol. Fish. Physiol. Biochem., 7: 253-258.

Pickering A.D., T.G. Pottinger, J. Carragher, J.P. Sumpter, 1987: The effects of acute and chronic stress in the levels of reproductive hormones in the plasma of mature brown trout, Salmo trutta L. Gen. Comp. Endocronol., 68: 249-259.

Prost M., A. Sopińska, L. Guz, 1995: Aktywność procesów obronnych ryb jako wskaźnik skażenia środowiska wodnego [Activity of defensive process of fish as indicator of water environment contamination].Medycyna Wet., 5: 275-279. (In Polish). 
Robertson L., P. Thomas, C.R. Arnold, 1988: Plasma cortisol and secondary stress responses of cultured red drum (Sciaenops acellatus) to several transportation procedure. Aquacult., 68 : $115-130$.

Soivio A., M. Nikinmaa, 1981: The swelling of erytrocytes in relation to the oxygen affinity of the blood in the rainbow trout, Salmo gairdneri Rich. In: Stress and fish [A.D. Pickering (ed.)], Academic Press: 103-119.

Thomas D., 1990: Molecular and biochemical responses of fish stressors and their potential use in environmental monitoring. Am. Fish Soc. Symp., 8: 9-28.

Thomas P., 1984: Influence of some environmental variables on the ascorbic acid status of mullet, captured-stress and temperature. J. Fish Biol., 25: 711-721.

Van Overbeeke A.P., J.R. McBride, 1971: Histological effects 11-ketotestosterone, 17-methyltestosterone, estradiol cypionate and cortisol on the intereenal tissue, thyroid gland and pituitary gland of gonadoextomized sockeye salmon Oncorhynchus nerka. J. Fish. Res. Bd. Can., 28: 477-484.

Weisbart M., P.K. Chakrabarti, F. Gottschall, H.C. Freeman, 1989: Effect of acid environments on cortisol and cortisol receptor actiovity in Atlantic salmon, Salmo salar. Fish Physiol. Biochem., 3: 267-274.

Weggrzynowicz R., E. Gorczyńska, 1982: Neuropatomechanizm stresu u ryb [Stress neuropathomechanism in the fish]. Now. Wet., 4: 234-238.

\section{Mariola FRIEDRICH}

\section{WPŁYW TRANSPORTU I ZMIANY ŚRODOWISKA NA POZIOM ACTH I KORTYZOLU WE KRWI KARPIA (CYPRINUS CARPIO L.)}

\section{STRESZCZENIE}

Doświadczenie przeprowadzono na karpiach $\mathrm{w}$ wieku +1 , hodowanych $\mathrm{w}$ kanale wody pochlodniczej elektrowni Dolna Odra. Celem pracy było określenie wpływu transportu na stężenie ACTH i kortyzolu we krwi oraz ocena czasu jaki musi upłynąć od przewozu i zmiany środowiska do powrotu stężeń oznaczanych hormonów do stanu podstawowego. Stwierdzono, że transport spowodował statystycznie istotny $(\mathrm{P}<0,01)$ wzrost stężen $\mathrm{ACTH}$ i kortyzolu we krwi, a umieszczenie ryb w akwariach pomimo dogodnych warunków i zachowania tych samych parametrów wody, spowodowało przedhużenie się reakcji stresowej i utrzymanie wysokiego stężenia analizowanych hormonów ponad 7-dniowy, obserwowany okres.

Authors' address:

Mariola Friedrich PhD DSc Prof

Division of Fish Physiology

Agricultural University of Szczecin

Kazimierza Królewicza 4, 71-550 Szczecin, Poland 